\title{
Analysis of accident fatalities on South Sulawesi Inter-urban Roads
}

\author{
Muhammad Akram Ramadan ${ }^{1}$ and Martha Leni Siregar ${ }^{1 *}$ \\ ${ }^{1}$ Civil Engineering Department, Faculty of Engineering, Universitas Indonesia, Depok, Jawa Barat \\ 16424, Indonesia.
}

\begin{abstract}
Traffic accidents are the fundamental yardstick for road safety. In South Sulawesi, particularly the four road sections which become the main focus of this study are Jeneponto-Bantaeng, Bantaeng-Bulukumba, Bulukumba-Tondong, and Sengkang-Impa-impa. Topographic conditions in South Sulawesi generally have various surfaces, including road sections area of this study focus. These various topographical conditions cause a chance of a traffic accident to occur at a certain point on the geometric features of the road, either on a straight or bend road/ curve road, grad (+) or grad (-), or the influence of the average International Roughness Index (IRI) value of a road. This study aims to analyze significant road geometric features that determine the fatality rate of the traffic accident. The results obtained from this study are significant factors of geometric road features that statistically affect and determine the fatality rate of traffic accidents; namely road geometry, road gradient, and IRI value, or with the conclusion is that all predictor variables are significant factors in influencing fatality rate of the traffic accident.
\end{abstract}

\section{Introduction}

\subsection{Background research}

South Sulawesi Province, which has capital in Makassar, is located on Sulawesi Island. Its area is approximately $45,764.53 \mathrm{~km}^{2}$, with 24 regencies/cities in the South Sulawesi region [6]. Among them are Jeneponto, Bantaeng, Bulukumba, and Wajo, which is the research location. This research focuses on four inter-urban roads: Jeneponto-Bantaeng, BantaengBulukumba, Bulukumba-Tondong, and Sengkang-Impa-impa as in Figure 1. On BulukumbaBantaeng road, 25 fatalities resulted from 16 fatal accidents in 2019, as obtained from the police report in IRSMS [5]. The topography in South Sulawesi generally has various surfaces with mountains and sea distribution in 24 regencies/cities, including the road section of this research focus. With these varying topographical conditions, it is possible for traffic accidents to occur at certain points on the geometric features of the road, whether on a straight or bend road, descend or upward, or the influence of the road median and other geometric features.

\footnotetext{
*Corresponding author: leni@eng.ui.ac.id
} 
As one of the areas with a quite congested movement between regions, South Sulawesi has the opportunity to run a traffic accident. For the road sections of this study focus, which have heavy movement, the traffic accident's occurrence is possible. Besides, it is influenced by the condition of the geometric features covering along the road section that increases the probability of traffic accidents, both on a straight or bend road, descend or upward, median provisioning, and road roughness / IRI condition. Thus, this study analyzes the significant factors of geometric road features on the fatality rate of traffic accidents in South Sulawesi, especially in the four roads, namely Jeneponto-Bantaeng, Bantaeng-Bulukumba, Bulukumba-Tondong, and Sengkang-Impa-impa.

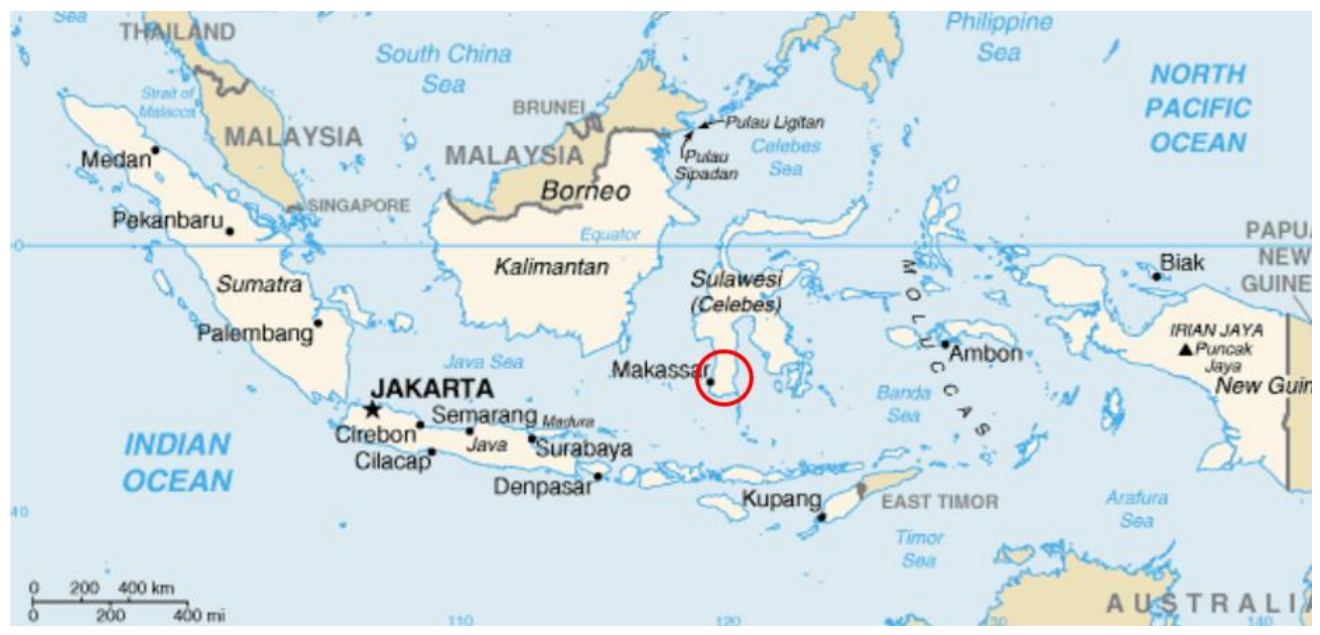

Fig 1. Location of Survey Roads in South Sulawesi as indicated by the circle, Indonesia [6]

\subsection{Theoretical Review}

A traffic accident is defined as an incident on the road that is unexpected and accidental involving a vehicle with or without other road users resulting in human casualties or property loss in the Article 93 of Government Regulation Number 43, 1993 [1]. According to Wells [19], accidents are caused by many factors, not just bad drivers or careless pedestrians. The main factors that cause accidents are generally caused by the driver (Road User), vehicle factors (Vehicle), road environmental factors (Road Environment). Moreover, the geometric condition of the road is one of the causes of traffic accidents. The geometry of roads and transportation systems is in such a way to influence road users' behavior and reduce and prevent accidents. At least the geometric design considers the interrelated objectives, i.e., to provide adequate safety and driving comfort and maneuvering, consider economic aspects, and ensure consistency of alignment. Previous studies have been conducted on traffic safety related to various predictors [2,3]. The determination of road alignment is also important. Even road alignment greatly affects the driver view's freedom, which affects the smooth traffic flow or endangers traffic. With geometry defined in bends and gradients, the present study incorporates road surface condition as a determining factor in road accidents.

Multinomial logistic regression analysis is a logistic regression used when the response variable is polychotomous or multinomial, nominal, and ordinal scales with more than two categories [16]. The multinomial logistic regression model is a model that focuses on the effect of a set of independent predictor variables on the response variable. This method can handle situations with several categories. There is no need to limit the analysis to pairs of 
categories or collapse the categories into two mutually exclusive groups to use the (more familiar) logit model [12].

Logistic regression analysis scrutinizes the relationship between response variables, which usually consist of qualitative data with explanatory variables consisting of qualitative and quantitative data. Multinomial logistic regression is an extension of binary logistic regression, whether the response variable has more than two categories with categorical and continuous explanatory variables. The logistic regression equation, in general, is as follows [7]. The equations used in logistic regression are:

$$
\pi_{k}(x)=\frac{\exp \left(\beta_{0 k}+\beta_{1 k} x_{1}+\cdots+\beta_{p k} x_{p}\right)}{\sum_{m=1}^{k} \exp \left(\beta_{0 m}+\beta_{1 m} x_{1}+\cdots+\beta_{p m} x_{p}\right)}
$$

By performing a logit transformation at $\pi(x)$, the following equation is obtained:

$$
\begin{aligned}
& P_{1}(x)=\ln \left(\frac{(P(Y=1) 1 \mid x)}{(P(Y=1) 0 \mid x)}\right)=\beta_{10}+\beta_{11} x_{1}+\cdots+\beta_{1 b} x_{b}=x^{\prime} \beta_{1} \\
& P_{2}(x)=\ln \left(\frac{(P(Y=1) 2 \mid x)}{(P(Y=1) 0 \mid x)}\right)=\beta_{20}+\beta_{21} x_{1}+\cdots+\beta_{1 b} x_{b}=x^{\prime} \beta_{2}
\end{aligned}
$$

\section{Method}

The data were obtained from EINRIP Report [4] and IRSMS [5]. In line with the study's aims, the study's scope covers the factors of road geometry as curves or straight, gradients, and road surface as IRI. The International Roughness Index (IRI) value indicates the roughness of the road surface, and bigger IRI values mean the surface is rough. The values had been received from longitudinal measurements of the roads. The street geometry is represented as curves and instantly sections, and terrible and advantageous gradients. Segmentation becomes primarily based on the element exam of the report's engineering drawings [4]. The roads are divided into segments primarily based totally on the extrude of geometric capabilities ensuing in 262 road segments.

In this study, the authors use multinomial logistic regression analysis by considering the number of dependent variables with more than one variable, namely minor, serious, and fatal injuries or death, while the independent variables are categorical in scale. Logistic regression can be used with two categorical dependent variables, so it is often called binary logistic. Some other formulas can even be used for more categories, in this case, called Multinomial Logistic Regression [9]. Multinomial Logistic Regression or the Polytomous Logit Model is a generalization of the binary logit model. In this context, "binary" means having two dependent variables, while "multinomial" has three or more categories [14]. Based on this explanation, this study uses the multinomial logistic regression analysis.

The response variable is traffic accidents, which consist of 3 categories, i.e., death, major injury, and minor injury [10]. The predictor variable includes three variables with a nominal scale that can be seen in the following table 1: 
Table 1. Research Variables

\begin{tabular}{|c|c|c|}
\hline No & Variable & Scale/Category \\
\hline 1 & Accident Fatality Rate (Y) & $\begin{array}{l}\text { Nominal } \\
Y(1)=\text { minor injury } \\
Y(2)=\text { major injury } \\
Y(3)=\text { fatal/death }\end{array}$ \\
\hline 2 & Geometric & $\begin{array}{l}\text { Nominal } \\
\text { X1 (1) = Straight } \\
\text { X1 }(2)=\text { Curve }\end{array}$ \\
\hline 3 & Gradient & $\begin{array}{l}\text { Nominal } \\
\text { X2 (1) = Grad (-) } \\
\text { X2 (2) = Grad (+) }\end{array}$ \\
\hline 4 & IRI & $\begin{array}{l}\text { X3 }(1)=<3.1 \\
\text { X3 }(2)=>3.1\end{array}$ \\
\hline
\end{tabular}

\section{Results and discussion}

\subsection{Analysis of descriptive statistical}

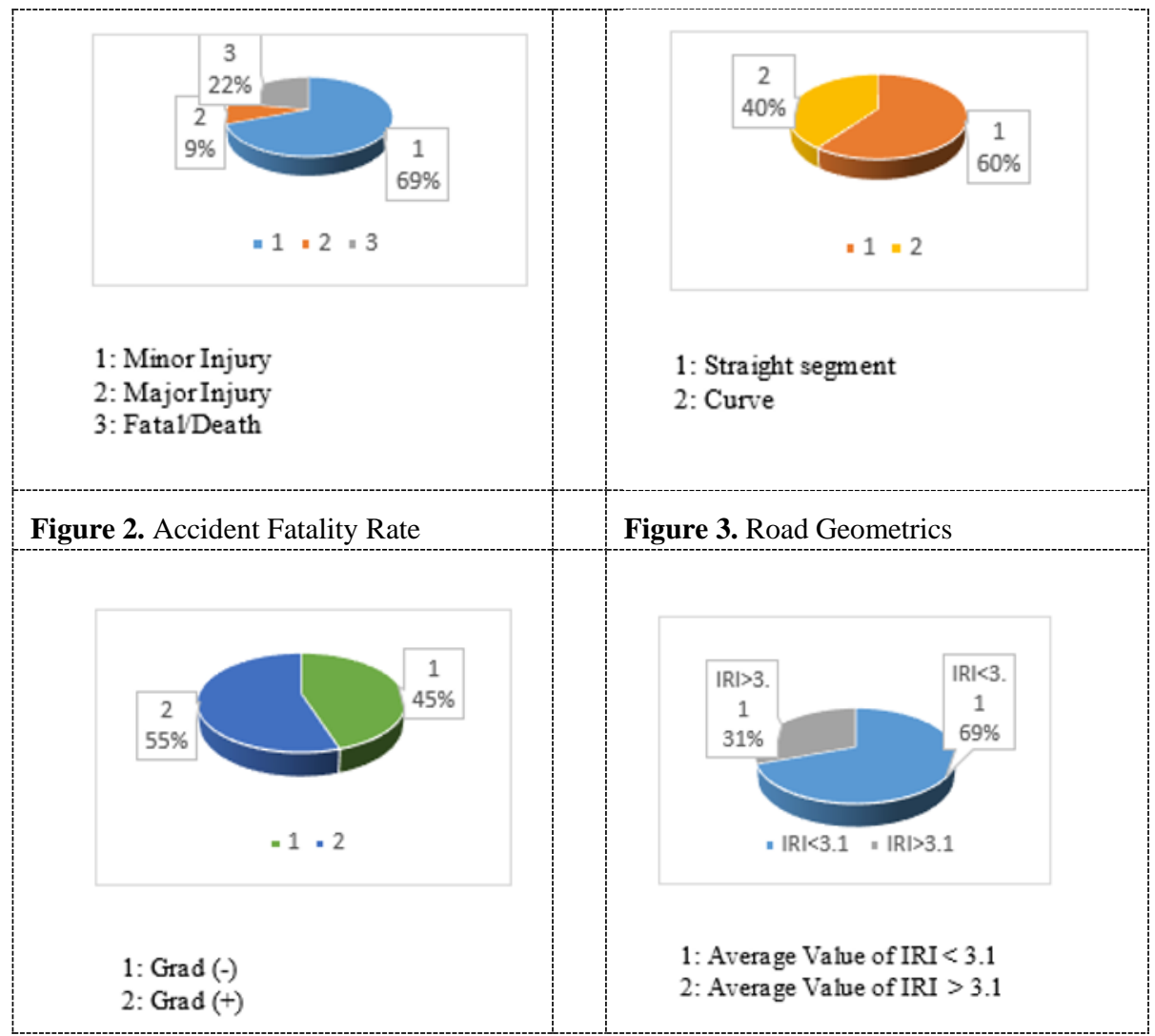


Figure 4. Road Gradient

Figure 5. IRI Value

From the descriptive results using the pie chart, the result in figure 2 shows that out of the 609 total number of traffic accidents, the accident fatality rate in the category of minor injuries was the most common in the 2013-2016 range with a percentage of $69 \%$, fatal or death was $22 \%$, and $9 \%$ for serious injuries. In figure 3 , most of the traffic accidents, which were $60 \%$, happened on the straight geometric conditions; meanwhile, the remaining $40 \%$ happened on the curved road.

Figure 4 shows that traffic accidents mostly occurred on upward or grad (+) roads with a large percentage of $55 \%$, while the other $45 \%$ were on descend road conditions or with negative gradient values ( $\operatorname{grad}(-)$ ). Figure 5 shows that the percentage of accidents at the IRI value $<3.1$ was $69 \%$ and greater compared to the IRI value $>3.1$, which was $31 \%$. Consider the descriptive analysis; this data has not many variants due to categorical data; therefore, it will then be processed using multinomial logistic regression ( $\mathrm{Y}$ variable is more than two categories and without no level).

\subsection{Logistic multinomial regression analysis}

Testing of Significant Parameters:

- Concurrent Test

Table 2. Results of Concurrent Test

\begin{tabular}{|c|c|c|c|c|}
\hline Model & $\begin{array}{c}\text { Model } \\
\text { Fitting } \\
\text { Criteria }\end{array}$ & \multicolumn{3}{|c|}{ Likelihood Ratio Tests } \\
\cline { 2 - 5 } & $\begin{array}{c}-2 \text { Log } \\
\text { Likelihood }\end{array}$ & $\begin{array}{c}\text { Chi- } \\
\text { square }\end{array}$ & df & Sig. \\
\hline Intercept Only & 117.391 & & & \\
\hline Final & 93.756 & 23.635 & 6 & .001 \\
\hline
\end{tabular}

Rejection Area $\mathrm{H} 0$ :

Reject $H 0$ if $G>\chi 2(d b, \alpha)$.

The statistical test and referring to table 2 show that the $\mathrm{G}$ value of 93,756 is greater than the value of $\chi 2$, which is 23,635 , and the P-value 0.001 is smaller than 0.1 , which means Reject H0. Thus, it can be concluded that with a confidence level of $90 \%$, there is at least one variable that has a significant effect on the level of fatalities in South Sulawesi between 2013 and 2016. Testing is applied simultaneously to the level of accident fatality in South Sulawesi. The Simultaneous Significance Test results in a decision to Reject HO to be continued in partial (individual) testing.

- Partial Test (Individual)

Individual tests were conducted to determine the significance of parameter $\beta$ on the individual response variables [11]. Where $\beta k$ is the parameter estimator of $\beta k$ and $S E^{n}(\beta k)$ is the standard error estimate.

Rejection Area $\mathrm{H} 0$ :

Reject $H 0$ if $|W|>Z \alpha 2$, or Sig Value <Alpha (10\%) 
After doing the individual test (partial), it can be seen in the column "Sig" that the significance value or P-value is less than $10 \%$. It means that all categories of variables are used significantly to the model, in order that the model used is quite good.

The following explanation is the data interpretation of each independent variable based on individual test tables or parameter estimates:

Table 3. Results of Parameter Estimation

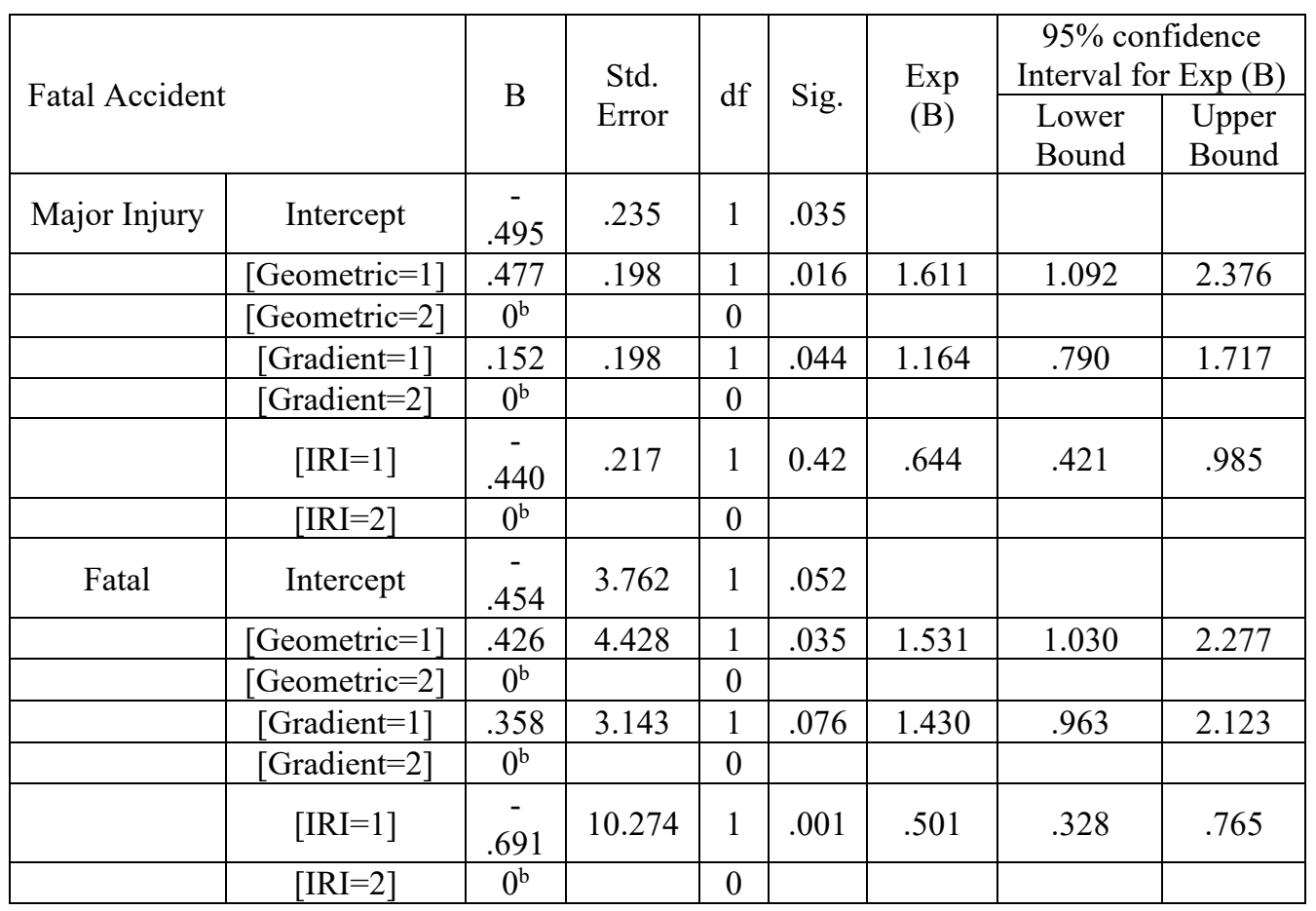

\subsubsection{Road Geometry}

The curvature is the control category for the probability value or exp B on the dependent variable minor injuries. For the risk of serious injury, traffic accidents on straight roads tend to have a risk of serious injuries (rather than minor injuries) 1,611 greater than those on a curved road. Meanwhile, for the risk of fatal injury or death, accidents that occur on straight roads have a risk of experiencing fatal injuries or death (rather than minor injuries) 1,531 greater than those on a curved road. Also, in table 3, it can be seen that the Wald value of the straight road is 5,788 , with a significant value of 0.016 for serious injuries, and fatal injuries or deaths is 4,428 with a significant value of 0.035 . The significant values of 0.016 and 0.035 are smaller than the significant level of $10 \%$, so it can be concluded that the Ho reject the hypothesis or the geometric factor of straight roads has a significant effect on the traffic accident fatality rate. It can be deduced that the geometric curves, which are categorized as control, have a significant effect on the fatality rate of traffic accidents with a smaller probability of accident risk compared to straight roads.

This study shows a higher risk of serious and fatal injuries on a straight road than on a curved road. This result is supported by other research conducted in Padang [20]. This research stated that many accidents occurred on straight roads with $55.07 \%$ compared to the 
curved one. However, it is different from other research that stated that the number of accidents on road bends was 1.5 to 4 times more than on the straight section of the road [17]. Other researchers also mentioned that the percentage of deaths and damage due to traffic accidents around the bend was $25-30 \%$ compared to straight roads [13].

\subsubsection{Road Gradient}

The gradient $(+)$ shows the incline in the road gradient variable is defined as the control category. For the fatality risk of serious injuries, roads on downhill or descent conditions have a risk of experiencing major injuries (rather than minor injuries) 1,164 greater than roads with upward conditions, whereas, for the risk of fatal injury or death, roads on downhill or descent condition tend to have a risk of fatal injuries or death (rather than minor injuries) 1.1430 greater than those of upward roads. Moreover, in table 3, the Wald gradient value (-) or a descending road is 0.591 with a significant value of 0.044 for serious injuries, and for fatal injuries or deaths, it has a Wald value of 3.143 with a significant value of 0.076 . The significant values of 0.044 and 0.076 are smaller than the significant level of $0.1(10 \%)$; it can be deduced that the Ho reject hypothesis or gradient factor of the downward/descending road has a significant effect on the traffic accident fatality rate.

The geometric factor of the uphill road, which is the control category, can be concluded to have a significant effect on the fatality rate of traffic accidents with a smaller chance of accident risk than a downhill road. A study in Semarang showed that the value of a positive or incline gradient had a higher risk of accidents than a descend road's condition at the same lane width [15]. The research conducted by Ridlo et al [15] is different from the results of this study, that the descend roads are more likely to cause accidents than the upward roads.

\subsubsection{IRI Value}

In the IRI value variable, an average IRI value $>3.1$ is defined as the control category. For the risk of fatality for serious injuries, roads with an average IRI value of $<3.1$ has a risk of serious injury (rather than minor injuries) 0.644 greater than roads with an average IRI value of $>3.1$. Meanwhile, for the risk of fatal injury or death, roads with an average IRI value of $<3.1$ tend to risk fatal injuries or death (rather than minor injuries) 0.501 greater than roads with an average IRI value of $>3.1$. Table 3 shows that Wald's average IRI value is $<3.1$ or 4.121 with a significant value of 0.042 for serious injuries, and fatal or dead injuries it has a Wald value of 10.274 with a significant value of 0.001 . The significant values of 0.042 and 0.001 are lower than the significant level of $0.1(10 \%)$; it can be concluded that the Ho reject the hypothesis or the road factor with an average IRI value of $<3.1$ has a significant effect on the traffic accident fatality rate. The road factor with an average IRI value of $>3.1$, which becomes the control category, can be concluded to significantly affect the fatality rate of traffic accidents with a lower probability of accident risk compared to roads with an average IRI value of <3.1. Even though it has different trend values, the IRI score's two categories indicate that roads are in good condition or the maintenance stage. Consequently, the IRI value significantly affects the traffic accident fatality rate.

This study shows that the average value of IRI tends to cause accidents. In research conducted on the Krian-Balongbendo By-pass road section, the level of road surface roughness or IRI was one of the road factors that cause accidents on these roads. In this study, 
the number of accidents caused by surface unevenness was ten accidents or in a percentage of $4.37 \%$ [18]. Another study that supports IRI as an influence on the accident fatality rate is a study conducted by Evi Puspitasari and Latif Budi S [8]; it was said that the IRI value influenced accidents, especially in dark conditions or at night. IRI's effect on the risk of accidents during dark conditions was discussed in research by, and it was stated that IRI influenced dark conditions. The reason is that road damage is invisible for road users during the dark condition. Road users are unable to control the speed of their vehicles well when facing damaged roads.

\subsection{Classification accuracy}

Table 4. Results of Accuracy of classification of influence factors

\begin{tabular}{|c|c|c|c|c|}
\hline \multirow{2}{*}{ Fatality Rate } & \multicolumn{4}{|c|}{ Predicted } \\
\cline { 2 - 5 } & Minor & Major & Fatal/Death & $\begin{array}{c}\text { Percent } \\
\text { Correct }\end{array}$ \\
\hline Minor & 218 & 43 & 6 & $51.8 \%$ \\
\hline Major & 53 & 12 & 2 & $22.6 \%$ \\
\hline Fatal/Death & 117 & 25 & 34 & $25.3 \%$ \\
\hline $\begin{array}{c}\text { Overall } \\
\text { Percentage }\end{array}$ & $63.7 \%$ & $27.6 \%$ & $8.7 \%$ & $59.6 \%$ \\
\hline
\end{tabular}

Table 4 explains the classification accuracy of the model that has been formed, which is $59.6 \%$. In other words, the number of correct predictions is classified according to observations (real conditions), and the result of classification error is $40.4 \%$. This model statistically can be said to be a fairly good prediction model. However, the accuracy of the prediction is still low, and therefore it is necessary to improve the used variables or additional variables or additional data to predict the level of accidents in South Sulawesi.

\subsection{Dependency test}

Table 5. Results of Dependency test

\begin{tabular}{|l|l|l|l|l|}
\hline \multicolumn{1}{|c|}{ Variable } & \multicolumn{1}{|c|}{$\mathbf{G}$} & \multicolumn{1}{c|}{$\mathbf{X}^{\mathbf{2}}$} & $\mathbf{P}$-value & \multicolumn{1}{c|}{ Decision } \\
\hline $\mathrm{X} 1$ to $\mathrm{Y}$ & 8.929 & 8.915 & 0,012 & Reject Ho \\
\hline $\mathrm{X} 2$ to $\mathrm{Y}$ & 4.139 & 4.138 & 0,013 & Reject Ho \\
\hline $\mathrm{X} 3$ to $\mathrm{Y}$ & 12.724 & 12.694 & 0,002 & Reject Ho \\
\hline
\end{tabular}

Based on the results above, it can be seen that each predictor variable, namely road geometrics, gradient, and IRI, is related to the severity of traffic accidents at the $10 \%$ significance level. Furthermore, a multinomial logistic regression modeling will be created with the independent variables, namely road geometric, road gradient, and IRI.

Based on the estimated parameter values in table 3, it can be used to explain the logistic function 1 (major category) and logistic function 2 (fatal category), so that the comparison function is the minor injury category. Hence, the multinomial logistic regression model is as follows: 
Where:

$$
\begin{aligned}
& \pi_{1}(x)=\frac{\exp g_{1}(x)}{1+\exp g_{1}(x)+\exp } g_{2}(x) \\
& \pi_{2}(x)=\frac{\exp _{2}(x)}{1+\exp g_{1}(x)+\exp g_{2}(x)}
\end{aligned}
$$

$\pi 1(x)=$ probability function for serious/major injury

$\pi 2(x)=$ probability function for fatal injury or death

- Logistics function 1 (for major injuries)

$$
\begin{aligned}
g_{1}(x)= & -0.495-0.477 X_{1}(1)+0 X_{2}(2)+0.152 X_{2}(1)+0 X_{2}(2)-0.440 X_{3}(1) \\
& \quad+0 X_{3}(2) \\
= & -0.495-0.477 X_{1}(1)+0.152 X_{2}(1)-0.440 X_{3}(1)
\end{aligned}
$$

- Logistic function 2 (for fatal injuries or deaths)

$$
\begin{aligned}
g_{1}(x)= & -0.454-0.426 X_{1}(1)+0 X_{2}(2)+0.358 X_{2}(1)+0 X_{2}(2)-0.691 X_{3}(1) \\
& \quad+0 X_{3}(2) \\
= & -0.454-0.426 X_{1}(1)+0.358 X_{2}(1)-0.691 X_{3}(1)
\end{aligned}
$$

\subsection{Model fit test}

Table 6. Results of Model fit test

\begin{tabular}{|c|c|c|c|}
\hline & $\begin{array}{c}\text { Chi- } \\
\text { square }\end{array}$ & df & Sig. \\
\hline Pearson & 23.373 & 8 & .292 \\
\hline Deviance & 24.302 & 8 & .204 \\
\hline
\end{tabular}

The fit test results of the multinomial logistic regression model between the severity of traffic accidents with road geometry, road gradient, and IRI show that the P-Value is 0.292 . The PValue is more than the $\propto$ value of $10 \%(0.292>0.10)$. The conclusion fails to reject $H 0$, so the result of the model is suitable (there is no significant difference between the observation results and the predicted results) and applicable.

\section{Conclusion}

All predictor variables, namely geometric, gradient, and IRI values, are significant road geometrics factors that affect the traffic accident fatality rate at the $10 \%$ significance level. Smaller values of IRI decrease the risk of both fatality and serious injuries. The present study's findings can help improve road safety conditions, particularly on inter-urban roads, to create more sustainable cities and communities.

\section{Acknowledgements}

The present study was funded by Universitas Indonesia PITTA B Grant 2019, contract number: NKB0751/UN2.R3.1/HKP.05.00/2019. The Authors would also like to thank the 
Project Management Unit of the Australian-funded "EINRIP Monitoring \& Evaluation Programme, Fifth Monitoring Survey, Final Report 2017" for the permission to use the data.

\section{References}

1. Ministry of Transportation of the Republic of Indonesia, Peraturan Pemerintah Republik Indonesia Nomor 43 Tahun 1993 Tentang Prasarana dan Lalu Lintas Jalan (Jakarta: Departemen Perhubungan, 1993)

2. Shinstine. DS, Wulff. SS, Ksaibati. K, Factors associated with crash severity on rural roadways in Wyoming, J. Traffic Transp. Eng. Engl. Ed. 3, 4, 308-323 (2016)

3. Wang. C, Quddus. M, Ison. S, The effects of area-wide road speed and curvature on traffic casualties in England, J. Transp Geo. 17, 5, 385-395 (2009)

4. Einrip Monitoring \& Evaluation Programme, Fifth Monitoring Survey, Final Report (2017)

5. Data Laka Login, http://irsms.korlantas.polri.go.id, accessed 2019 Mar 23

6. Agency for Regional Development of South Sulawesi Province (2014)

7. Agresti. A, An Introduction to Categorical Data Analysis, (John Wiley and Son, New York, 2002)

8. Budi. L, Evaluation of Road Surface Stability Based on the International Roughness Index, Urb. and Env. (2018)

9. Hair. J, Black. W, Babin. B, \& Anderson. R, Multivariate Data Analysis Seventh Edition, (Perason Education Limited, 2014)

10. Hobbs. F, Traffic Planning and Engineering Second Edition, (Pergamon Press, 1979)

11. Hosmer. D, \& Lemenshow. S, Applied Logistic Regression, (New York, John Wiley \& Sons, 2000)

12. Kwak. C, Matthews. C-Alan, Multinomial Logistic Regression Methode, Nurs. Res. 51, 6, 404-410 (2002)

13. Pamungkas. N, Analisis Karakteristik Kecelakaan dan Faktor-Faktor Penyebab, J. Tek. (2011)

14. Retherford. R, \& Choe. M, Statistical Model for Causal Analysis, (New York: Honolul : A Wiley-Interscience Publication, 1993)

15. Ridlo. S, Ismiyati, Izazulfina, \& Amelia, Analisis Hubungan antara Kelandaian Jalan dan Panjang Landai Kritis Terhadap Keselamatan Lalu Lintas (Studi Kasus: Ruas Jalan Setia Budi Semarang dari KM 8+100 sampai KM 9+350), J. Kary. Tekn. Sip. 2, 4, (2013)

16. Starkweather. J, \& Moske. A. K, Multinomial Logistic Regression, (2011)

17. Taufiq, N., Hidayat, M., Kusuma, A., \& Purwanto, D. Karakteristik Kecelakaan Lalu Lintas Pada Tikungan Rawan Kecelakaan di Jalan Pantura Jawa Tengah, J. Kary. Tekn. Sip. 7, 1, 131-141, (2018)

18. Utomo. N, ANALISA FAKTOR PENYEBAB KECELAKAAN LALU LINTAS PADA SEGMEN JALAN BY-PASS KRIAN - BALONGBENDO (KM. 26+000 KM. 44+520), J. Tekn. Sip. KERN. 2, 2, (2012)

19. Wells. G, Rekayasa Lalu Lintas, Edisi Kedua (Jakarta, Bharatara, 1995)

20. Zayu. P, Kecelakaan Lalu Lintas dengan Metode Revealed Preference di Kota Padang, (Research Graduated Program, Universitas Andalas, Padang, 2012) 